\title{
Robots, Extinction, and Salvation: On Altruism in Human-Posthuman Interactions
}

\author{
Juraj Odorčák *(1) and Pavlína Bakošová
}

Centre for Bioethics UCM, Department of Philosophy and Applied Philosophy, University of Sts. Cyril and Methodius in Trnava, 91701 Trnava, Slovakia; p.bakosova@yahoo.com

* Correspondence: juraj.odorcak@ucm.sk

check for

updates

Citation: Odorčák, Juraj, and Pavlína Bakošová. 2021. Robots, Extinction, and Salvation: On Altruism in Human-Posthuman Interactions. Religions 12: 275. https://doi.org/ $10.3390 /$ rel12040275

Academic Editor: Takeshi Kimura

Received: 1 April 2021

Accepted: 12 April 2021

Published: 16 April 2021

Publisher's Note: MDPI stays neutral with regard to jurisdictional claims in published maps and institutional affiliations.

Copyright: () 2021 by the authors. Licensee MDPI, Basel, Switzerland. This article is an open access article distributed under the terms and conditions of the Creative Commons Attribution (CC BY) license (https:// creativecommons.org/licenses/by/ $4.0 /)$.

\begin{abstract}
Posthumanism and transhumanism are philosophies that envision possible relations between humans and posthumans. Critical versions of posthumanism and transhumanism examine the idea of potential threats involved in human-posthuman interactions (i.e., species extinction, species domination, AI takeover) and propose precautionary measures against these threats by elaborating protocols for the prosocial use of technology. Critics of these philosophies usually argue against the reality of the threats or dispute the feasibility of the proposed measures. We take this debate back to its modern roots. The play that gave the world the term "robot" (R.U.R.: Rossum's Universal Robots) is nowadays remembered mostly as a particular instance of an absurd apocalyptic vision about the doom of the human species through technology. However, we demonstrate that Karel Čapek assumed that a negative interpretation of human-posthuman interactions emerges mainly from the human inability to think clearly about extinction, spirituality, and technology. We propose that the conflictual interpretation of human-posthuman interactions can be overcome by embracing Čapek's religiously and philosophically-inspired theory of altruism remediated by technology. We argue that this reinterpretation of altruism may strengthen the case for a more positive outlook on human-posthuman interactions.
\end{abstract}

Keywords: robot; extinction; altruism; posthumanism; transhumanism; Karel Čapek; humanmachine interactions; eschatology; soteriology

\section{Introduction}

This year marks the hundredth anniversary of the first staging of the play R.U.R.: Rossum's Universal Robots (Čapek 1920), which introduced the term "robot"1 to the canonical pantheon of modern imagery. Karel Capek's ${ }^{2}$ nomenclature later inspired the grounding for serious scientific inquiry (robotics), and today, various kinds of robots are not just mere conceptual tools, but actually do (some of) our work. Nevertheless, Čapek was also heavily criticized by some authors (i.e., Asimov [1995] 2003) for the apocalyptic nature of R.U.R. Critics argued that Karel Čapek infected the public understanding of robots with misleading prophecies about the impending doom of the human species through technology (extinction). Many academic publications have focused on the destructive part of Čapek's

1 Some authors assume that the term "robot" originally denotes a slave (Naughton 1984, p. 73; Liu 2010, p. 6; Belk et al. 2020, p. 225). The term "robot" is a shortened and personified version of the Czech word "robota", which in the Czech language was an expressive notion for hard work (drudgery) or even work in general. The term "robot" was invented by Josef Čapek (Čapek [1924] 1966, p. 105) who was interrupted in his work on a painting by his brother, Karel Čapek. Karel complained that he had not come up with a satisfactory name for the hardworking protagonists of his play; therefore, Josef proposed that Karel should simply name them "roboti" (hard workers), thus the term was a polite way of Josef to say to Karel that they both need to go back to work. The slave connection also does not find a firm ground in R.U.R. as Alquist was spared by robots not because he was a slave, but precisely because robots perceived him as equal, as a man who works. Moreover, the term "robota" was at that time frequently used in parts of Czechoslovakia as a prefix for occupations of factory workers ("robot-nik", work-er) and later the Slovak language version of the Constitution of the Czechoslovakian Socialistic Republic (1960) even claimed that the "robot-nicka trieda" (work-ing class) has definitely seized the means of production, albeit it was not entirely true. From hereafter, if not otherwise stated, the term "robot" will refer to Karel Čapek's notion of robots.

2 From hereafter, if not otherwise stated, the name Čapek will refer to Karel Čapek. 
literary work. However, substantially less research has examined the constructive vision of Čapek's philosophy. This is not surprising, as the finale of R.U.R. points to extinction. Yet Čapek also concluded his explication of robots with the transformation of the stoic Alquist into a paradoxically fervent believer in technology, despite the looming extinction (Alquist case). Some authors dismissed Čapek's conclusions with remarks about naïve, vague, and open beliefs (Naughton 1984, p. 86; Howell 1984, pp. 123-24; Parrinder 2015, pp. 158-59). The supposed naivety of Čapek's beliefs is the prime target of this article. There are two reasons for this. First of all, Capek's relationship with beliefs and religion is overwhelmingly underdeveloped in the academic literature. The notable exemptions are the commentaries in the works of Verra Vášová (1930); Azriel Rosenfeld (1966); Yvonne Howell (1984); Kamila Kinyon (1999); Ivan Klíma (2002); Jiří Opelík (2016); and Lyne Badia (2019). We intend to contribute to this debate by exploring a novel link between Čapek, transhumanism, posthumanism, and religious ${ }^{3}$ implications. We argue that Čapek's understanding of religion, philosophy, and robots may be much more complex than it is sometimes assumed to be (Sections 3 and 4). Second, as was noted before, Čapek's vision is still perceived as an example of a technophobic work by some authors; however, the perspective may fundamentally change if one includes Čapek's view on religion and philosophy in his understanding of robots (Section 5). From this point of view, Čapek's philosophy is then not just about who is to blame, but moreover, an explication of his pragmatic notion of hope despite the reality of a probable extinction of the human species. We elaborate on this notion of hope by its reinterpretation through the contemporary theories of transhuman and posthuman salvation (or quasi-salvation) (Section 6), and we argue that altruism remediated by technology may strengthen the case for a more positive understanding of human-posthuman interactions. But before continuing with the explication of positive relations, let us start with a story about a small revolution.

\section{The Robot Uprising}

The first humans who ever dared to be like robots received a punishment for their transgression-not from a god, but from Universum, which was a production company that had exclusive rights to the first staging of Čapek's play R.U.R.: Rossum's Universal Robots (Veis 2020, p. 6). The official premiere of R.U.R. was planned to be staged at the National Theatre in Prague at the end of December 1920 (Koreis 2008, p. 9), albeit it was postponed to the end of January due to technical and production issues (Černý 2000, p. 91). Meanwhile, a group of dedicated railway workers and amateur actors called Klicpera ${ }^{4}$ had already been through all of their rehearsals of R.U.R. and planned for their presentation of the play to be held on 2 January 1921 at the theatre in Hradec Králové (Horáková and Kelemen 2008, p. 294). The Universum company and the National Theatre mailed the Klicpera group about the delay of the official premiere in Prague and prohibited them from staging an unofficial performance in Hradec Kralove's theater. The amateur actors decided to ignore the notice, burned the letter ${ }^{5}$ (Veis 2020, p. 6), and performed their debut of R.U.R. anyway (Černý 2000, p. 91). The performance was a success (Anonymous 1921, p. 7) and the determined group performed the prohibited staging of R.U.R. once again the very next day. Universum reprimanded Klicpera for their misconduct. The group was charged with a fine of more than 1200 Czechoslovak crowns (Anonymous 1927, p. 1), a sum which then amounted to four monthly wages of a factory worker (Prücha 2004, p. 59). Hence, the first men who pretended to be robots that wanted to be like men and therefore rebelled against them were punished by other men that wanted to be robots sooner than the first men.

3 We will use the term religion (religiousness) in the broad sense of symbolic and spiritual mediation of the world. For a review of this approach to the relation between robots, technology, religion, and society, see the works of Takeshi Kimura (Kimura 2017), Sandu Frunză (Frunză 2019), and Robert. M. Geraci (Geraci 2020). For a review of interconnections between science and religion, see the work of Miroslav Karaba (Karaba 2021).

4 The play was directed by Bedřich Stein, who was a railway inspector by profession (Horáková and Kelemen 2008, pp. 294-95).

5 The inspiration for this act is obvious since the burning of the essential instruction for the design of the robots is one of the main dramatic plots of R.U.R. (Čapek 1920, pp. 49-50). Helena Glory burns the design in revenge against robot factory owners after she learns that the global human infertility is probably caused by technological unemployment of humans. 
The official premiere ${ }^{6}$ of R.U.R. was staged at the National Theatre on 25 January 1921. Čapek's play seemed to deeply reflect the popular spirit of that time, as it later achieved an impressive number of domestic reruns (Pilný 2021, p. 142) and the first foreign adaptation was performed right away in the same year in Aachen (Černý 2000, p. 91). Performances in New York, Warsaw, Belgrade, and several other major cities followed the next year (Koreis 2008, p. 9). By the time (1923) the robots triumphally marched into theaters in London, Berlin, Vienna, and Zurich, R.U.R. had already been translated into thirty languages (Strätz 2017, p. 634). In the next decade, R.U.R. was performed on most major stages around the world7 (Černý 2000, p. 93), and today the term "robot" is commonly used in more than eighty different languages (Katsev 2021).

However, Čapek's play has also, from the start, attracted a rather large number of disputes about the true nature of its final message. For example, even the first review of the rebellious unofficial presentation of R.U.R. praised the play for its firm stance against totalitarianism but lamented the absurd philosophical tirades of Alquist (Anonymous 1921, p. 7). The anonymous reviewer even proposed that a change to the end of R.U.R. would bring about more balanced interest from viewers regarding the main political theme of the play (Anonymous 1921, p. 7). Similar distress, luckily not about the authors' creative rights but about the interpretation of the meaning of R.U.R., was also apparent in international receptions of the play. For instance, the British premiere of R.U.R. was followed by a public dispute between George Bernard Shaw and Gilbert Keith Chesterton ${ }^{8}$. They both perceived the play as a warning but disagreed about the character of the threat. Chesterton perceived R.U.R. as a play warning against modern alienation (Harkins 1962, p. 91). Shaw supposed that it was a work opposing the social passivity of modern man (Sparks 1997, p. 171). Additionally, this conflicting interpretation was not unique. Even the man whose work (Asimov [1950] 2004), along with Čapek's nomenclature, later motivated various fields of human inquiry (robotics) argued that the play helped to reinforce a global Frankenstein complex (Asimov [1995] 2003, p. 195). This may have had something to do with the quality of the first English translation of R.U.R. ${ }^{9}$, which omitted some parts of the original version and "consequently might have deprived the dramatic text of its complexity" (Ambros 2009, p. 144); nevertheless, it is also true that the play inspired numerous academic reviews of the apocalyptic implications of R.U.R. (Naughton 1984; Clarke 2000; Grübler 2014; Porter 2017, pp. 239-40) and countless pop-cultural references to the idea that robots may one day terminate mankind. Hence, Čapek's play is still perceived by some as a dark play (Bostrom 2005, p. 7). Yet R.U.R. also ends with the spiritual epiphany of Alquist about the life-saving potential of technology (robots). The correct understanding of robots therefore crucially depends on the explication of Čapek's belief in the rationality of hope, thus on his account of religion and philosophy.

\section{3. Čapek, Religion, and Society}

Karel Čapek was a Roman Catholic by denomination (Halík 2008, p. 4). Čapek's critical relationship with religion started relatively early and was introduced to him mostly by the disputes between his devout grandmother and scientifically disposed father (Čapek [1926] 2000a, p. 71). Čapek sided with his father and he, in his student years, became a

6 The director of the official production was Vojta Novák. Costumes were designed by Karel Čapek's brother Josef Čapek (Horáková and Kelemen 2008, p. 295).

7 To name a particularly successful instance, Miri Nakamura argued that the introduction of Čapek's play “brought about a robot boom in modern Japan. Books on 'how to make your own artificial human being' began to appear as children began to exhibit their homemade robots at middle and high school exhibitions" (Nakamura 2007, p. 173).

8 Chesterton later noted about the debate that: "[T]here came on me that mysterious and elusive feeling of which Wordsworth wrote, and which many psychologists have noted as a mystery of the mind ... And the difference does not merely concern him [Shaw] and me, but hundreds of other people who are thinking what can be done with modern mechanical civilization" (Chesterton [1923] 1986, p. 134).

9 The first English translation of R.U.R. was completed by Paul Selver and adapted prior to its appearance in print by Nigel Playfair (Čapek 1923). Selver omitted some parts of the original version in his translation-for example, the last sentence where Alquist exclaims that life will "Not perish!" (cf. Čapek 1920, 1923). The reasons for Selver's and Playfair's editorial input are a matter of ongoing dispute (see Abrash 1991; Philmus 2001; Pilný 2021, pp. 144-46). R.U.R. was translated into English seventy years later with much greater accuracy by Claudia Novack-Jones (Čapek 1990). 
member of the Czech faction of the Libre Penseé (Free Thought) movement (Opelík 2016, p. 78). Young Čapek was radically anticlerical and thought about religions mainly in terms of the struggle between the beliefs in old hierarchical structures and the requirements for the novel social reorganization of the declining Austro-Hungarian Empire. His stance on faith was, at that time, primarily guided by the sociological ${ }^{10}$ implications of religions, and his utilitarian outlook on public matters later became one of the staples of his philosophical and metaphysical inquiries (see Section 3).

After the First World War, Čapek also frequently contributed to public disputes about the political role of religions in the civic life of the young Czechoslovak republic. This public dispute led him to the well-known conflict with Jaroslav Durych, who was, at the time, a prominent Catholic intellectual. Durych insisted on the essential role of categorical moral principles, and through several references to moral relativism, hypocrisy, and historical ignorance (Durych et al. [1926] 2001, pp. 206-7), he indirectly accused Čapek of a secret plot to downplay the role of Christianity in the formation of the modern world (Berglund 2017, pp. 210-11). Čapek contested with remarks about Durych's harmful politicization, polarization, and militarization of religion (Čapek [1926] 2000a, p. 72). The dispute between them lasted for several more years, and it escalated for the last time when both were defending radically opposing views on the interpretation of the Spanish Civil War (Med 2006, p. 3). Durych portrayed Čapek's support for the Republican's cause as an expression of anti-Catholicism (Nelis et al. 2015, p. 327). Additionally, after Čapek's death ${ }^{11}$, one of the more grotesque obituaries even noted an end of the "enemy number 3 of the Czech nation and its Catholic-Christian consciousness" (Renč 1939, p. 6). This so-called "hunt on Čapek"12 (Bauer 2001, p. 4), which was closely associated with the political hysteria of that period ${ }^{13}$, was later condemned by several Catholic intellectuals (Putna 2008; Halík 2018).

However, Čapek's actual relationship with religion was much more complex than some political columnists have painted it to be. Almost all of his major works entail, in one way or another, references to religious or spiritual themes (e.g., Továrna na absoltno (The Absolute at Large) (Čapek [1922] 1982), Věc Makropulos (The Makropulos Case) (Čapek [1922] 2005), and Adam Stvorittel (Adam the Creator) (Čapek and Čapek [1927] 1982)). Čapek also asserted that a proper knowledge of religion is a quintessential prerequisite for any culturally literate person (Šiška 2010). Perhaps this is the reason why Čapek also frequently used biblical imagery to convey messages about his critical worldview and philosophical ideas (Čapek [1945] 2016). His arguments were usually crafted in an ironic manner-for example, in one instance, he explained his theory of truths through the mouth of Pontius Pilate (cf. Čapek [1920] 2016) —and therefore, he always risked misunderstandings about the nature of his opinions on religion. Moreover, Capek did not write any extensive systematical work dedicated exclusively to religion or a critique of religion per se; thus, his notions of religion are sporadically scattered across a plethora of fictions, commentaries, and personal correspondences.

Nevertheless, Čapek's philosophy of religion can be broadly defined through his three general notions of religiousness: political religiosity, practical religiosity, and spiritual religiosity. Political religiosity, no matter the inclination, seemed to Čapek to be straightforwardly harmful and dangerous. He argued that a zealous political religiosity, which he believed was built on a substantial connection between power and religion, was not actual

10 Čapek was not oblivious about the religious prospects of social movements and vice versa. He, for example, once pointed out that "[e]very church has something; catholic holidays, socialist strikes" (Čapek [1919] 1995, p. 9). Čapek later also frequently warned about the dangers of the zealous glorification that, according to him, plagued modern social mass movements (cf. Čapek [1924] 2000b).

11 Karel Čapek died on 25 December 1938.

12 Some authors argue that this "hunt" continued even after the second world war, alas through a propagandistically reversed order of the campaign (Bauer 2001, p. 4). After the Second World War, Durych's works were banned and he lived in seclusion. Jaroslav Durych died on 7 April 1962 (Komárek 2014, p. 106).

13 Some authors indicated that the Gestapo, before the occupation of Czechoslovakia, had already prepared an arrest warrant for Čapek (Sriratana 2018, p. 13). Karel's brother Josef Čapek was arrested by the Gestapo in September 1939. He was transferred to Bergen-Belsen concentration camp and died there, probably in April 1945 (Sayer 2018, pp. 125-26). 
religion, but rather a religion worshipping unbound power (Čapek [1926] 2000a, p. 75). However, his evaluation differed on the matter of the other two types of religiousness. The conception of practical religiosity, which he repeatedly introduced through the example of his devout grandmother, seemed to him as a worthwhile expression of a deep belief in morality and, hence, a manifestation of a common —and, therefore, authentic - quest for social fairness (Čapek [1926] 2000a, p. 67). Čapek frequently used this concept of practical religiousness (which, in his eyes, implied experienced and not just ostensibly expressed religiousness) as a barrier against the attacks of the many aforementioned critics (Čapek [1926] 2000a, p. 75). Čapek even seemed to favor this so-called humble religion (Čapek [1918] 2018, p. 45), as it complemented his concept of civility (Čapek [1936] 1986, p. 697). Alas, this did not preclude him from various teasing remarks about the variability of this type of religiousness (i.e., Nana in R.U.R.).

The last aspect of Čapek's philosophy of religion is closely tied with his perception of spirituality. Capek's notion of spirituality was guided by his reception and critique of, among others ${ }^{14}$, Leo Tolstoy. Čapek was, for reasons that have already been mentioned, inquisitive about the concepts of simple Christianity, and his understanding of Tolstoy introduced him to the concept of transcendence through unification. Čapek perceived Tolstoy as an anachronistic philosopher who, regardless of that, managed to properly grasp the mystical vitality and dynamism of human empathy (Čapek [1909] 1984, p. 59). Hence, Čapek mostly associated spirituality with virtues of altruism; therefore, he also criticized every attempt that was perceived by him as contradictory to this substantial relationship between religion and the world. On the other hand, this probably also led Čapek to his famously benevolent view of the attitudes of the common man and his proportionally firmer requirements for humanity. Perhaps this is also one of the reasons why Čapek later described the last man, Alquist, as Tolstoyan (Čapek [1923] 1995, p. 157). In essence, Čapek's understanding of religion can be best characterized as a derivative of his sociological standpoints, although this did not preclude him to form a religiously inspired take on numerous broader philosophical matters.

\section{4. Čapek, Philosophy, and Society}

The young Čapek hoped to become a natural scientist (Langer 1971, p. 133), but instead started studying philosophy, philology (French, English, and German studies), aesthetics, and the history of art (Čapek [1915] 1987), and later became a well-known writer, journalist, poet (Klíma 2002, p. 7), and even an enthusiastic amateur photographer (Scheufler 2000, p. 5). His philosophical writings (student and early period), artistic expressions, and professional publications (career and late-career period) were tied together by his general interest in the prospects of rational inquiry into the state of modern humanity.

Čapek was attracted to research on a method that could, somehow, unite different aspects of reality without a loss of authenticity. The obvious target for his philosophical study was, therefore, the intersection of science, philosophy, and $\operatorname{art}^{15}$. His dissertation was dedicated to the analysis of the possibility of an objective method in aesthetics (Čapek [1915] 1987, p. 124). He argued—contrary to psychologism (emotivism), hedonism, and aestheticism - that aesthetic data, judgments, and values may have objective components that are transferred, and therefore, also sometimes obfuscated, through a complex series of practical engagements in the common lifeworld (Čapek [1915] 1987, p. 241). Čapek thus believed that an objective method in aesthetics and philosophy (and life in general) was just an expression of a pursuit of authenticity, where for him, authenticity depended on the requirements of humans to act and to believe in something-namely, on

14 For a review of Čapek's relationship with Chesterton, see Bradbrook (1977).

15 Čapek's systematical philosophical writings were latter published as Univerzitní studie (University Studies) (Čapek 1987). They entail his dissertation Objektivní metoda v estetice se zřením k výtvarnému uměni (Objective Method in Aesthetics With a Focus on Fine Arts) (Čapek [1915] 1987), along with his seminar works Směry v nejnovější estetice (Movements of Contemporary Aesthetics) (Čapek [1913] 1987), Poměr estetiky a dějin umění (The Relationship Between Aesthetics and Art History) (Čapek [1914] 1987), and Pragmatismus čili Filosofie praktického života (Pragmatism, or Philosophy of Practical Life) (Čapek [1918] 1987) 
the necessity of humans to be. Every rigid and ante res divide between subjects, objects, and their perceived worlds seemed doubtful to him, even though he did not believe in any kind of straightforward reductive monism (Čapek [1919] 1985, pp. 110-11). Čapek tried to occupy the middle ground between monism and dualism. Additionally, for him, the middle ground was always the praxis (pluralism); thus, he believed that reality may have different facets, but that all of them come together by virtue of the practical aspects of dayto-day life (Čapek [1918] 1987, p. 325). Actual life, not the life of self-absorbed emotions or abstract theoretical classifications, then became the guiding philosophical principle in much of Čapek's work.

However, relatively early on, he also took note that something might be wrong with modern humans and their spiritual relationship with nature, culture, and themselves (Čapek and Čapek [1918] 1982, p. 5). The young Čapek thought that the problematic nature of these relations was a specific outcome of misguided ideas about progress, namely, the European understating of progress that was, according to him, plagued by recurring visions of a past golden age (Čapek [1913] 2018, pp. 13-14). Čapek argued that modern European culture was deceived through a concept of progress that proposed-in today's terms-future developments, but that as a rule, always paradoxically pointed to heralded victories of the long-gone past. European cultural historicism and hermeticism seemed deeply ahistorical and problematic to Čapek, and this tension between the future and the past appeared to him as the prima facie reason for the cultural malaises of the modern $\operatorname{man}^{16}$. This uneasiness about the true nature of progress and the modern human predicament accompanied Čapek's thoughts about society and became an essential component of the conflict between the metaphysics of the Old Rossum (old, heroic reasons for progress) and the ontology of the Young Rossum (new, pragmatic reasons for progress).

\section{Robot Precursors: Pragmatism, Futurism, and Vitalism}

According to one popular story (Horáková 2005, pp. 95-96), Čapek conceived the idea for R.U.R. on his morning commute to work, where he, for reasons not entirely specified, had to take an unusually long detour from his ordinary route by hopping on a suburban tram. The speeding tram was fully packed with workers who were hurrying to their morning shifts in many of the factories that had emerged around post-war Prague at that time. Capek later stated that he was utterly flabbergasted with the stoic nature of his peers, who were patiently completing their commute even on the steps of an accelerating tram ${ }^{17}$ (Čapek [1933] 1986, p. 502). He concluded from the experience that the symbolic tram of our civilization was also guided by similar goals, rituals, and even stepping options. However, the main problem of the ride was the meaning of the endpoint, which was nowhere to be seen. Or maybe it was, but not from the perspective of the individual that was neatly pressed into the tram. Nevertheless, Čapek also understood that individuals of modern societies were not just repressed or acting against their interests (Čapek [1930] 2000, p. 64). Contrary to that, the ordinary passengers and the dedicated engine driver were following obvious pragmatic rules and had precise reasons for their behavior. Every one of them had, or could have if needed, a perfectly true assertion for the validity of their particular actions. The different passengers may have had diverse or even contradictory reasons for completing their day-to-day rides, but the tram on its own moved precisely because of all of these discrepancies (different stations). Hence, according to Čapek, there

16 At that time, Čapek believed that this was specifically a European problem. He described European ideas of progress mostly in contrast to the-as he perceived them-rational, pragmatic, and nonreligious attitudes toward progress espoused by American intellectuals (Čapek [1913] 2018, p. 14). Čapek later adjusted his position (cf. Čapek [1926] 2000b), mainly due to his concerns about the normative presuppositions of Taylorism, which became one of the subthemes of R.U.R.

17 The "tram story" has sometimes been used as evidence for Čapek's abrupt shock about the dehumanizing conditions of common men, which later supposedly led him to the elaboration of the notoriously rebellious plot of R.U.R. (Naughton 1984, p. 85). This may be the case, but at the time, Čapek hardly could have been oblivious about the unfortunate conditions of his blue-collar peers, as he grew up in a small industrial and mining town, where he as a child had "galloped so many times through the black dust of the working-class neighborhoods ..., that no one will ever fool you [him] that there is little misery, vice, filth, and horror in the world" (Čapek and Čapek [1918] 1982, p. 5). 
is not just one truth but many of them, which may compose yet another truth (Čapek [1926] 2000c, p. 48), namely, the truth of a (public transport) system.

Čapek also noticed that some ideologies have taken this system of truth to be, by the merits of unification, the one and only truth, the common truth (Čapek [1924] 2000b, p. 76). However, on account of the aforementioned objective method, he did not believe in any higher or lower tastes; thus, he also did not suppose any soundness in hierarchical theories about truths (Čapek [1918] 1987, p. 275). For him, absolutism and subjectivism about truth are both established through the false idea of competition for the seats of truths. The bold absolutist needs to win the competition at any cost, and the daring subjectivist always tries to fight for the sake of rivalry. Both fight because both believe that they are in mortal danger from the reality of the truths or the truth. Čapek assumed that there was no reason at all to conceive the reality of truth as deceptive or deficient because truths just are, they just live their life (Čapek [1918] 1987, p. 325). Hence, Čapek was a social pragmatist ${ }^{18}$ and an ontological relationist ${ }^{19}$ who supposed that different truths not only coexist but also, by the virtue of this, add up to yet another layer of truths (Čapek [1926] 2000c, p. 48). Therefore, just as there are truths of particular humans and their common works, there are likewise also truths that are not entirely human or just for the benefit of humans. The tram also has truth, technology can be true; thus, the prerequisite for the sociology of the robot was born.

However, it is not enough to mean something. Objects, subjects, trams, and truths need to be somewhere. Where, then, is the modern system, which is packed with many passengers and their diverse truths, heading? As was previously noted, Čapek's concern about the future started relatively early, mainly through his interest in the proper definition of progress. Interestingly enough, Čapek's ideas about progress were not only formed by his social and scientific concerns but moreover by his appraisal of avant-garde art movements. Čapek's liaison with futurism was started by his semester abroad at Sorbonne in 1911, where he, together with his brother Josef ${ }^{20}$, attended several lectures, exhibitions, and became aware of the works of, among others, Filippo Marinetti (cf. Čapek [1912] 1984a, p. 197). Čapek was mostly impressed ${ }^{21}$ by Marinetti's theories about the direct and active role of art (i.e., Marinetti [1909] 2006) and by the futuristic proposals for a creative reconfiguration of the relationship between art, science, technology, and society (i.e., Balla and Depero [1915] 2009). It seemed to him that futurists managed to explicate the problem of preoccupation with the future more openly than the other movements of that time because Marinetti's heroical and comical slogans systematically undermined culturally common notions of a convenient way out of progress (Čapek [1913] 1984, p. 349). Čapek perceived futurists as critics of false promises about a naïvely transparent future, and Marinetti's Extended Man (Marinetti [1910] 2006) appeared to him, at the time, as an ironic personalization of this tendency (Čapek [1913] 1984, p. 349). However, Čapek also later became a stark critic of futurism. Aside from the obvious political reasons ${ }^{22}$, Čapek criticized futurism from the perspective of epistemology and ethics, as he supposed that pessimism and ironical optimism may, in the end, both result in a deluded appraisal of the future and the past (Čapek [1924] 2000a, p. 53). Moreover, futurists typically propagated a future where they would become unbound supreme machines, but from the point of

18 Čapek's pragmatic position was primarily shaped by his examination of the works of William James, John Dewey, and Ferdinand Canning Scott Schiller (Čapek [1918] 1987, pp. 336-38).

19 Čapek's ontological position was formed through a plethora of diverse works, notably by his critical reception of the works of George Simmel (Čapek [1914] 1984b), Henry Bergson (Čapek [1914] 1984a; Čapek [1920] 1985; Čapek [1929] 1986), and positivism (Čapek [1914] 1984c; Čapek [1919] 1985).

20 The Čapek brothers became fervent propagators of futurism in Czechoslovakia, which subsequently led to their conflict with the older generation of Czechoslovakian intellectuals and avant-garde artists (Lamač 1988, p. 184). Josef Čapek wrote the first Czech review of futurism (Čapek 1912). For a more comprehensive analysis of Josef Čapek's complex relation to futurism, see Odorčák (2021).

21 Karel Čapek also established correspondence contact with Marinetti and translated some of his works (Catalano 2013).

22 Čapek later admitted that, before the First World War, he also supported futurism for political reasons, as he perceived them (and their philosophy) as allies of his own fight against the old establishments (and philosophies) of the Austro-Hungarian Empire (Čapek [1932] 2000, p. 113). However, during the war, Čapek became a strident opponent of the political ambitions of futurism (Čapek [1932] 2000, p. 115) because they were, prima facie, contradictory to Čapek's lifelong belief in democratism (Ort 2013, p. 7). 
Čapek's pragmatic ontological relationism, it seemed entirely possible that machines could become more human and, at the same time, nonhuman, just like the many other systems that were created and perpetuated by humans. Therefore, it seemed to Čapek that futurists propagated a future, but in the end, actually had a deformed past of a golden age in mind (Čapek [1924] 2000a, p. 53), an age of Titans with speeding motorcycles, trains, and planes. Thus, even the young Rossums may, if they try hard enough, become old Rossums. Čapek supposed that this was the prime example of the futuristic misunderstandings about the real power of progress. He believed that real progress occurs for much more mundane reasons and has far more intimate consequences for both humans and machines; thus, Čapek began to think about robots not as gods or exotic puppets (i.e., poupee electrique), but as common ordinary beings and passengers of the world system.

The last aspect of R.U.R. robots stems from Čapek's confrontation with vitalism. Interestingly enough, Čapek presented his most extensive work on vitalism (Čapek [1920] 1985) in the same year he published R.U.R. ${ }^{23}$ Čapek understood vitalism mostly as an optimistic attack on the positivistic interpretations of reality (Čapek [1929] 1986, p. 180). Bergson's philosophy appeared to Čapek as a laudable program for a critical reconstruction of the past shortcomings of mechanistic psychology and restrictive metaphysics (Čapek [1920] 1985, p. 162). Čapek also sympathized with the naturalism of vitalism, as he had assumed that the variability of biological explanations of reality is a far more appropriate approach to the world than the explications of simplistic physical determinism (Ćapek [1920] 1985, p. 160). The central role of life in vitalism likewise corresponded with Čapek's persistent inclination towards praxis (as opposed to abstraction) ${ }^{24}$. Moreover, according to Čapek, the evolutionary aspect of vitalism implicated opportunities for novel theoretical approaches and creative insights into the ontology and aesthetic of objects ${ }^{25}$. Bergson's vitalism at the time had a wide appeal, extending into the realm of literature, culture, and art (Normandin and Wolfe 2013, p. 8). Capek therefore supposed that the diverse manifestation of life as described by Bergson may point to an interesting theory (i.e., vitalism), but besides that, these transformations of life could also open a future for the disintegration of barriers between subjects, objects, nature, and culture (Čapek [1920] 1985, p. 162). Hence, Čapek's understanding of vitalism was based primarily on an attempt at a practical reinterpretation of Bergson. From the perspective of this pragmatic understanding of vitalism, even artifacts may one day become an embodiment of élan vital, and Čapek combined these aspects of creative evolution in the ontology of his robots (Sleigh 2009, p. 246). However, the naturalization of artifacts is just one aspect of Čapek's notion of vitalism in R.U.R. The second part is the explication of his extensive critic of Bergson's vitalism (Jones 2018, pp. 295-96).

Čapek criticized Bergson for three main reasons. First of all, Bergson's rigid divide between intellect and intuition (Bergson [1907] 2012, p. 267) appeared to Čapek as counterintuitive, since every polarization of perception was contradictory to his firm belief in the plurality of truths and pragmatism. From the perspective of Čapek, Bergson rightly pointed out different facets of cognition but only to subordinate one aspect of perception to another one. Second, and more importantly, a similar dualism that is just a monism with extra steps, was, according to Čapek, apparent in the implication of Bergson's ontology. Bergson tried to free life from the prison of past reductionism by explicating the crucial role of life's variety. However, Čapek supposed that Bergson's uniform concept of life's variety could explain the variety in life only by erasing distinctive aspects of actual life forms (Čapek [1920] 1985, p. 181). Čapek argued that Bergson paradoxically sided with a monistic metaphysics of life, thus with a notion of an abstract life without a distinctive

23 Čapek wrote R.U.R. during his vacation in Trenčínske Teplice (present day Slovakia) in the summer of 1920 (Horáková and Kelemen 2009, p. 556). His main study of vitalism Filozofie Bergsonova. Henri Bergson: Vývoj tvořivý (The Philosophy of Bergson. Henri Bergson: Creative Evolution) was published in three successive parts on 30 April, 7 May, and 14 May 1920.

24 Čapek even associated vitalism with pragmatism. He maintained that both philosophies are committed to a version of practical naturalism (Čapek [1918] 2018, p. 45).

25 This is also the reason why Čapek related vitalism with futurism. In a review of the first exhibition of futuristic art in Prague, he described futurism and vitalism as complementary expressions of a new approach to time being of life and art (Čapek [1913] 1984, p. 349). 
practical feature (Čapek [1920] 1985, p. 182). He presumed that this also subsequently led Bergson to absurd visions about the insignificance of individuals, species, and their role in the constant flux of life, because if individuals and species are just a temporal extension of a theoretic abstraction - be it an extension of life force or something else- then their meaning is equally abstract, thus trivial. And that is false by the merits of a praxis of and in actual life. Čapek, therefore, contended that every livable theory needs metaphysical groundings for the last things of life since metaphysical self-sufficiency of death individuates beings for ontological and practical purposes (Čapek [1920] 1985, p. 182). Moreover, Čapek also pointed out that the genuine understanding of continuity and discontinuity of life, which is absent or empty in vitalism, is the basic principle of the fundamental knowledge and eschatology ${ }^{26}$ of every known religion (Čapek [1920] 1985, p. 182). Čapek posited that religions usually complete a person's personality by explicating a theory of limits of personal persistence (death) in relation to a concept of permanence (eternity) (Čapek [1920] 1985, p. 182). This crucial aspect was, according to Čapek, missing in Bergson's vitalism; therefore, he classified personal implications of vitalist ontology as problematic and deeply anachronistic. The main contra-argument against vitalist ontology is the problem of the last things of life, the problem of death. The need to acknowledge the reality of life and death of an individuum or a species, then, has taken up a prominent role in the narrative of R.U.R.

Čapek's third main critique of Bergson was targeted at the ethics of vitalism. Čapek argued that Bergson's monistic ontology of life indicates egoism as an essential characteristic of life since various offshoots of life compete against each other only for their portion on the life as such (Čapek [1920] 1985, p. 186). This, however, is for Čapek a hopelessly one-sided position as evidenced by the many examples of asceticism, generosity, and fellowship of humans (Čapek [1920] 1985, p. 186). Moreover, the conception of hereditary egoism (Čapek [1920] 1985, p. 186) is not only one-sided but also short-sided since it perpetuates an unresolvable conflict between life and death. Even the most egoistic attempt at life one day ends, thus the individual, in the end, always fails. The answer to this conundrum between life and death is, according to Čapek, selflessness (Čapek [1912] 1984b), which by the merits of companionship, transcends both personal life and personal death; thus, salvation is only possible through altruism. Only through altruism can a human (Čapek [1920] 1985, p. 183) or a robot (Čapek 1920, p. 96) become truly complete.

To sum it up, Čapek's conception of robots and humans can be reconstructed through relations between his sociological, philosophical, ethical, aesthetical, and spiritual views. Pragmatism enabled Čapek to see robots and humans as equals. Futurism rendered the narrative space for the progressive intersection between the aims of humans and the goals of artificial beings. Vitalism composed their shared claim on life, creation, death, and extinction. The answer to this conflict was Čapek's philosophically and religiously inspired belief in the fulfillment of personal life through altruism. No matter the biological groundings. Thus, if technology can somehow attribute to altruism, then technology can attribute to life's completion and Alquist may exclaim that "life will not perish".

\section{Salvation: Transhumanism and Posthumanism}

Though, they perished. Or to be more precise, the R.U.R. does not give any definitive notion on Alquist's fate, but since he is the last man and probably not immortal, then the end of his own life and the extinction of his species is settled. Moreover, Alquist also failed to supply the robots with vital reproduction and regeneration technology (Čapek 1920, p. 95), therefore even the robots are in probable danger of death and extinction. According to Čapek, R.U.R. was primarily a play about extinction and hope. He perceived the diverse and conflicting interpretations of his work as consequences of our innate inability to think clearly about humanity as a dead or dying race (Klíma 2004, p. 17). For

26 We use the terms eschatology and soteriology in the nonrestrictive meanings of these terms; therefore, we do not want to imply any bearings or relations to specific religious teaching about the last things and hope. On the other hand, Čapek's understanding of this topic comes mostly from his knowledge of Christianity and is associated with his reflection of the philosophy that was at that time prevalent. 
him, the play is about a message at the edge of humanity, about a vision conceived at the "grave of mankind" (Klíma 2004, p. 17), although if he wanted to be more accurate about the limits indicated in R.U.R., then perhaps he should have also included robots to the aforementioned fate. From this broader view, then, R.U.R. is not just about the apocalypse (and hope) of humans, but also a doubled take on a story about the apocalypse and extinction of humans and robots (or technology as such). We will not go down this path in this article since our focus is more on hope than doom.

Let us instead speculate that the robots at some point will, somehow, outlive Alquist, and thus humans. Let us suppose, as Alquist does, that humans will perish but the robots Helena and Primus are the new Eve and Adam (Čapek 1920, p. 96). The crucial question is, then, why are these artificial beings to Alquist the answer to his existential misery? If Čapek did not just want to show that humans are always delusional or that the last humans necessarily will go mad-which on its own would be an interesting story-then Alquist somehow must have established a shared connection to these artificial beings. The connection in R.U.R. is love, the property to make selfless sacrifices for another being (Čapek 1920, p. 96). Compassionate love is the only way to evolve into a more meaningful world (Delio 2020, p. 10). For Alquist, love seems to be the essential characteristic of humanity, and if love will be, somehow, protected by technology (Helena, Primus) even after the demise of humanity, then it all was not for nothing since there always will be something that was intimately shared by humans and robots. Or as Čapek put it, "even the most extreme pessimist would surely realize the divine significance of this extinct species and say; it was a great thing, to be human"27 (Klíma 2004, p. 17). The divine significance of the species, which Čapek was speaking of, was his spiritually inspired understanding of the essential role of altruism in life. Altruism that could go beyond the polarity of life and death of an individual or even a species. This also seems to be the reason why Alquist's existential angst in the end fades and he concludes with (and he is sketched in R.U.R. as a shy nonbeliever) biblical motives of fruitfulness, replenishment, and creation (Čapek 1920, p. 96). The liberating vision at "the grave of the mankind" is the prospect of hope remediated through an ongoing love. Hence, the continuation and explication of altruism seem to be Čapek's ${ }^{28}$ noble answer to death and extinction.

However, how exactly does this spiritual epiphany of Alquist help with the problem of death and extinction? Especially if we recall that Alquist, and with him, the whole of humankind, will perish. Even if we suppose that the robots continue their own life as a new Adam and Eve, then it is from the system content of R.U.R. hard to fathom how the continued existence of robots has any exact bearing on the death of Alquist or extinction of humans. The problem seems to be in the practical explication of this kind of soteriology that is based on hope in altruism which is, somehow, remediated through technology.

One of the more obvious explanations of this riddle is based on the fact that R.U.R. is just a play. No more, no less, a simple play. And since it is just a play, then the end of the play needs a more or less satisfactory closure. According to this interpretation, Čapek was simply in the dark and he ended up with love for the benefits of a passable happy ending. This interpretation maintains that the famous end, which was even altered in some of the international productions of R.U.R. (Pilný 2021, p. 144), was written by Čapek for the soothing comfort of an audience that could have been deprived by a story full of inhuman monsters, human madness, and a scene of vivisection of a human actor live on stage (robot Daemon) ${ }^{29}$. For all we know, this might have been the case, but it is certain that Čapek's concern about altruism which is presented in R.U.R. was not an occasional

27 Various sources indicate that this quote is form Čapek's article The Meaning of R.U.R. printed in the Saturday Review (136, 21 July 1923, 79) (See Klíma 2004, p. 7; . Richardson 2015, p. 37). The Czech version of the article titled Význam RUR (The Meaning of RUR) states the same date of the article; however, for some reason, it does not entail the quoted passage (cf. Čapek [1923] 1995, pp. 156-60).

28 According to one theory Alquist is, at least in part, the personalization of Čapek's philosophy of life and death. This theory is based on Čapek's favorable remarks about Alquist (cf. Čapek [1923] 1995, p. 157), as well as the name of the character. The name Alquist was probably derived from the Latin "aliquis" (someone), or from the Spanish "el quisto" (most favored) (Klíma 2002, p. 82).

29 This scene was in the original Czech production played behind glass and only in silhouette; however, on one occasion a viewer fainted during the scene (Černý 2000, p. 101; Pilný 2021, p. 145). 
theme of his work since the exposition of altruism was later developed in numerous of his other fictional and non-fictional works (i.e., Čapek [1945] 2016). Besides, as was previously noted, Čapek's philosophical critique of the so-called hereditary egoism of vitalism closely precedes his work on R.U.R. Several other philosophical works from his young period also point to his persistent analysis of essential characteristics of humans and humanism (Čapek [1912] 1984b; Čapek [1918] 1987). Though, it is also true that a certain melodramatic aspect is evident in the closure of R.U.R. Hence, the normative specifics of the Alquist case are relatively clear (love, altruism), but the precise technical implications are stated rather sparsely.

Nevertheless, from the contemporary perspective, which is much more accustomed to explications of precise technological solutions to life, there might be some derivative options on how to understand the promise of Čapek's posthuman altruism. The two options that are at hand are transhumanism and posthumanism ${ }^{30}$. For example, Nick Bostrom references R.U.R. in his seminal work about the history of transhumanist thought (Bostrom 2005, p. 7), Britta Schinzel includes the play in a list of transhumanistic fictions (Schinzel 2021, p. 215), Jennifer Keating and Illah Nourbakhsh describe parallels between R.U.R. and Kurzweil's The Singularity Is Near (Keating and Nourbakhsh 2019), and Milan M. Ćirković groups Čapek together with transhuman ideas about a superior stage in evolution (Ćirković 2020, p. 271). Needless to say, there are numerous forms of transhumanism and for this article, we will briefly sketch only two of them.

One prominent version of transhumanism is centered on the idea of maximization of an individual's potential through various biotechnological means (Pugh 2017, p. 8). This version of transhumanism explicates biotechnological transformations of an individual mostly as means for the benefit and well-being (in the broad sense) of that particular individual (Sigmund 2017, p. 2). This type of individualistic, hedonistic, or one might even say, entertainment transhumanism is, however, clearly far off from the promises and perils of Alquist. Another version of transhumanism, which we will label as protective transhumanism, is focused on the problem of species contingency. Protective transhumanism ${ }^{31}$ propagates the idea that various environmental (and other) challenges could one day existentially endanger our species, and as our external use of technology in the prevention of these risks has some limits, then it would be probably much more efficient to transform our current species into a new one. A new species that would, somehow, resist these challenges and risks. Protective transhumanism is dedicated to the prevention of extinction (Fox 2018, p. 7). It is quite clear that the presupposition of this type of transhumanism, in a way, very closely resembles the narrative settings of the end of R.U.R. Alquist faces extinction and another species of robots is the answer. Moreover, the robots of R.U.R. are usually associated with mechanical features (Potkonjak 2020, p. 7), but Čapek, in concordance with his notion of vitalism, defined robots as beings that were produced by an undisclosed form of biotechnology. Robots were created from the so-called protoplasm of life (Čapek 1920, p. 10). The end of R.U.R. can be-with a certain amount of generosityread as a story about an accidental moral enhancement ${ }^{32}$ that goes right and saves (almost) everybody. Robots are the answer to human extinction because tinkering with their delicate biology enabled them a capacity for empathy and altruism. And since Alquist believes that altruism is the essential property of the human species, then the human species does not go entirely extinct even after he dies, because humanity will be preserved through their artificial offspring, the charitable Helena and Primus, the new Eve and Adam. The Alquist case can be closed because humanity will be preserved through protective technology that

30 We do not want to insinuate by this choice that transhumanism and posthumanism are religious in their nature. For a more precise analysis of the religious associations of transhumanism and posthumanism, see the work of Jon Bialecki (Bialecki 2020) and Denis Byrne (Byrne 2019). For a review of utopian aspects of posthumanism and transhumanism, see the work of Mariusz Pisarski (Pisarski 2021).

31 We do not want to imply that these two versions of transhumanism are mutually exclusive, or exhaustive versions of transhumanism.

32 The story can be also read as a warning against unregulated and free-market enhancement. The robots were at the beginning more humanlike (Old Rossum), but the forces, spirit, and reasons of the market led to their simplification and downgrade (New Rossum). On the other hand, the rebellion of robots started after an experiment that enhanced some of their mediocre features. 
conserves a specific property. Hence, this kind of eschatology is completed with a promise about soteriology through a technological continuation of an essential property of humans, the property of altruism.

Although perhaps the problem is not the preservation of the right property but the right explication of altruism. The second option for the Alquist case is posthumanism. Authors that reflect posthumanism relatively frequently reference Čapek's work. For instance, Francesca Ferrando lists R.U.R. in the bibliography of several of her analyses of philosophical posthumanism (Ferrando 2019, p. 235; Ferrando 2015, p. 275), Ruben Borg relates Čapek with posthuman modernism (Borg 2019, p. 1), Marija Grech counts Čapek as a proto-posthumanist (Grech 2016, p. 5), and there are numerous interpretations of the posthuman otherness of Čapek's robots (LaGrandeur 2015; Ahamed 2021). However, as it is frequently stated, posthumanism is an umbrella term (Knox 2016, p. 3; Chesi and Spiegel 2020, p. 2), therefore there are also multiple types and subtypes of posthumanism. In this article, we will identify just two broad notions of posthumanism. The first type of posthumanism is constructed around a critique of our current institutions and society. Supporters of this type of social posthumanism usually maintain that the power relations of modern societies, which can be traced back to, for example, the presupposition of the Enlightenment Project (Baumlin 2020, p. 2), are primarily built on a discriminatory preference of humans before other-than-human beings (posthumans) (Schade and Askew 2019). Social posthumanism proposes a social reform of the ethical and legal relations between humans and other beings (Di Genio 2021, p. 264), and this type of posthumanism also recommends a methodological modification of the current approach to culture, science, and nature (Münster 2020, p. 7). The link between social posthumanism and the narrative structure of R.U.R. is pretty straightforward, since one of the main plots of the play is the complicated (and rather foolish) power relation between humans and robots, therefore the social premises of R.U.R. are quite well documented in research dedicated to posthumanism (i.e., Jones 2017). Our attention in this article is, however, dedicated to the conclusion of R.U.R., and in the case of Alquist, there was not much left for a reform. Except for his understanding of ontology.

Metaphysical posthumanism ${ }^{33}$ is primarily dedicated to the reconstruction of the relation between ontological categories. Metaphysical posthumanists argue that there were countless systems for ontological categorization (i.e., monism, dualism, reductionism), but they all equally have failed to describe reality. This type of posthumanism also supposes that the consequences of the failed categorizations can be found in the disastrous effects of our activities on nature (Anthropocene). The human obsession with categorization, divisions, classifications, extractions, and production enabled technological progress that created a global state of constant exposure of life to human ontological biases. The problem is not technology but the anthropocentrism of the global use of technologies. Metaphysical posthmanists therefore propose a non-anthropocentric understanding of ontology and technology. And to understand ontology and technology from this broader perspective, one must leave the position of human species metaphysical exceptionalism behind. One must embrace that the own species is not exceptional and just temporal. A temporal part in the constant flux of life that will start anew (Čapek 1920, p. 96). From this perspective, Alquist was not saved because he elaborated an intricate belief in the static preservation of special human property in other posthuman beings (robots), but because he had, in the end, through technological examples, realistically understood that human properties are not special at all. Moreover, if there were altruistic human deeds in the past, then the altruistic robots Helena and Primus, the new Eve and Adam, are an exceptionally discrete reminder that it really "was a great thing to be a human" (Klíma 2004, p. 17), while it lasted. Hence, this kind of salvation of Alquist is not built on his last attempt to transgress the boundaries

33 We are fully aware of the controversial nature of this label and we do not want to imply that these two versions of posthumanism are the exclusive versions of posthumanism. Posthumanists usually criticize metaphysical systems and metaphysical ideology. 
between species, but on his epiphany about the limits of species. And the technology just helps to display the essential message about the role of altruism in life.

Admittedly, both of these interpretations about a hopeful conclusion of R.U.R. may have many blank spots. For example, it is questionable that the altruism, which Alquist perceives and Čapek propagates, is actually that effective or essential. It is also uncertain if the transhuman Alquist would not be entitled to a problematic conception of species which would multiply ontological and logical problems for identity. It is likewise true that Čapek stated the meaning of the play exclusively in anthropocentric terms. Furthermore, it is also valid to claim that R.U.R. is a dark play about extinction, thus a play about the biopolitical horror of violence and finitude of humans (Anderson 2014). Nevertheless, our primary intention in this article was to show that Čapek's spiritual inferences in R.U.R. can be reconstructed through the analysis of his relationship with religion and philosophy, and the consequences of these relations can be reinterpreted even within the contemporary conceptions of technological salvation (or quasi-salvation). Whether any of these salvations actually work is a theme beyond the limited scope of this article.

\section{Conclusions}

Karel Čapek was not a transhumanist nor a posthumanist, he was a humanist (Čapek [1912] 1984b; Čapek [1922] 1985). Čapek's relation to humanism was complex and he described it as a pragmatic label for a theory that was conditional to the practice of beneficial interactions. Capek was driven by questions about the limits of these relations (Čapek [1934] 2018, p. 275). His philosophical inquiries were frequently targeted at limits of perception (aesthetic), limits of preferences (objective method), limits of truths (pluralism), limits of society (pragmatism), limits of beliefs (religion and spirituality), limits of progress (futurism), and limits of life (vitalism). Čapek believed that the borders between these limits can be crossed only when an individual overcomes the vanity of the barriers between humans. An individual is completed only by the assertion and practice of altruism, and humanism is fully complete only when it goes beyond humanity. Altruism is the answer because it goes beyond the temporal ontology of humans and humankind.

Čapek's robots are a tool for the explications of the contradictions between these limitations of humans and humanism. Humanity is led to destruction by human intentions, and technology multiplies the consequences of these actions. The inherent conflicts of humanism are presented in R.U.R. through the disagreement amongst humans and by the clash between humans and the technological other. The robots win, humans lose, and the tragedy of this loss was an inspiration to countless interpretations of the apocalyptic nature of R.U.R. Yet if one includes Čapek's view on philosophy and religion in the premises of the play, then the human-posthuman interactions are not only about loss but also about hope. Hope is in the technological mirror. Life will start anew because altruism could be included in the robotic genesis. Or life will start anew since altruism could be reflected throughout robots and all the other mirroring relations. Hence, R.U.R. can be reinterpreted through contemporary notions of transhuman and posthuman salvation (or quasi salvation) since it is foremostly Čapek's fictional commentary on the old problem of permanence and presence, a remark on the puzzling ability of humans to simultaneously accept and reject both life and death. The ability to understand this particular nature of humans can strengthen the case for more positive realizations of human-posthuman interactions.

Author Contributions: Both authors have contributed equally to the work. All authors have read and agreed to the published version of the manuscript.

Funding: This research was funded by Slovak Research and Development Agency, grant number APVV-17-0064 "Analysis of multidimensional forms of trans- and post-humanism".

Institutional Review Board Statement: Not applicable.

Informed Consent Statement: Not applicable.

Data Availability Statement: Not applicable. 
Conflicts of Interest: The authors declare no conflict of interest.

\section{References}

Abrash, Merritt. 1991. R.U.R. Restored and Reconsidered. Extrapolation 32: 185-92. [CrossRef]

Ahamed, Sahabuddin. 2021. The Crisis of the Human Existence in the 20th and the 21st Centuries: A Representation of the Ontological and the Practical Posthumanism in Karel Capek's Drama R.U.R. (Rossum's Universal Robots). In The Posthuman Imagination: Literature at the Edge of the Human. Edited by Tanmoy Kundu and Saikat Sarkar. Cambridge: Cambridge Scholars Publishing, pp. 115-23.

Ambros, Veronika. 2009. America Relocated: Karel Čapek's Robots between Prague, Berlin, and New York. In Performance, Exile and 'America'. Edited by Silvija Jestrovic and Yana Meerzon. New York: Palgrave Macmillan, pp. 134-57.

Anderson, Nicholas. 2014. Only We Have Perished: Karel Čapek's R.U.R. and the Catastrophe of Humankind. Journal of the Fantastic in the Arts 25: 226-46.

Anonymous. 1921. Premiera R.U.R. v Hradci Králové [Premiere of R.U.R. In Hradec Králové]. Kraj Královéhradecký: The Hradec Králové Klicper Theater, vol. 12, p. 7.

Anonymous. 1927. Kde byla premiéra R.U.R. [Where Was the Premiere of R.U.R]. Prague: Lidové Noviny, vol. 35, p. 1.

Asimov, Isaac. 2004. I, Robot. New York: Bantham Dell. First published in 1950.

Asimov, Isaac. 2003. Gold: The Final Science Fiction Collection. New York: Harper Collins. First published in 1995.

Badia, Lynn. 2019. The Absolute Indeterminacy of Karel Čapek's Science Fiction. Open Library of Humanities 5: 1-25. [CrossRef]

Balla, Giacomo, and Fortunato Depero. 2009. Futurist Reconstruction of the Universe. In Futurism: An Anthology. Edited by Lawrence Rainey, Christine Poggi and Laura Wittman. New Haven: Yale University Press, pp. 209-15. First published in 1915.

Bauer, Michal. 2001. Nebezpečný Karel Čapek [The Dangerous Karel Čapek]. Tvar 12: 4-5.

Baumlin, James S. 2020. From Postmodernism to Posthumanism: Theorizing Ethos in an Age of Pandemic. Humanities 9: 46. [CrossRef]

Belk, Russell, Mariam Humayun, and Ahir Gopaldas. 2020. Artificial Life. Journal of Macromarketing 40: 221-36. [CrossRef]

Berglund, Bruce R. 2017. Castle and cathedral: Longing for the Sacred in a Skeptical Age. Budapest and New York: Central European University Press.

Bergson, Henry. 2012. Creative Evolution. New York: Dover Publications. First published in 1907.

Bialecki, Jon. 2020. Future-Day Saints: Abrahamic Astronomy, Anthropological Futures, and Speculative Religion. Religions 11: 612. [CrossRef]

Bostrom, Nick. 2005. A History of Transhumanist Thought. Journal of Evolution and Technology 14: 1-25.

Borg, Ruben. 2019. Fantasies of Self-Mourning: Modernism, the Posthuman and the Finite. Leiden and Boston: Brill.

Bradbrook, Bohuslava R. 1977. Chesterton and Karel Čapek: A Study in Personal and Literary Relationship. The Chesterton Review 4: 89-103. [CrossRef]

Byrne, Denis. 2019. Prospects for a Postsecular Heritage Practice: Convergences between Posthumanism and Popular Religious Practice in Asia. Religions 10: 436. [CrossRef]

Čapek, Karel. 1984. Lev Nikolajevič Tolstoj [Lev Nikolayevich Tolstoy]. In O Umění a Kultuře I. Prague: Československý Spisovatel, pp. 59-61. First published in 1909.

Čapek, Karel. 1984a. Anthologie de L’Effort [Anthology of Effort]. In O Umění a Kultuře I. Prague: Československý Spisovatel, pp. 194-99. First published in 1912.

Čapek, Karel. 1984b. Literární Poznámky o lidskosti [Literary Notes on Humanness]. In O Umění a Kultuře I. Prague: Československý Spisovatel, pp. 171-80. First published in 1912.

Čapek, Karel. 1984. Výstava maleb italských futuristů [Exhibition of Italian Futurist Paintings]. In O Umění a Kultuře I. Prague: Československý Spisovatel, pp. 348-49. First published in 1913.

Čapek, Karel. 1987. Směry v nejnovější estetice [Movements of Contemporary Aesthetics]. In Univerzitní Studie. Prague: Československý Spisovatel, pp. 7-91, 121-260. First published in 1913.

Čapek, Karel. 2018. Úvahy Američana [Reflections of an American]. In Od Člověka k Člověku. Prague: Městská knihovna v Praze, pp. 12-15. First published in 1913.

Čapek, Karel. 1984a. Henri Bergson: Das Lachen [Henri Bergson: The Laughter]. In O Umění a Kultuře I. Prague: Československý Spisovatel, pp. 394-97. First published in 1914.

Čapek, Karel. 1984b. Mamelet: Le Relativisme philosophique chez Georg Simmel [Mamelet: Philosophical Relativism in Georg Simmel]. In O Umění a Kultuře I. Prague: Československý Spisovatel, pp. 400-5. First published in 1914.

Čapek, Karel. 1984c. Sociální filozofie. Ke kritice školy Durkheimovy [Social Philosophy. To criticize the Durkheim school]. In O Umění a Kultuř I. Prague: Československý Spisovatel, pp. 359-68. First published in 1914.

Čapek, Karel. 1987. Poměr estetiky a dějin umění [The Relationship between Aesthetics and Art History]. In Univerzitní Studie. Prague: Československý Spisovatel, pp. 92-120. First published in 1914.

Čapek, Karel. 1987. Objektivní metoda v estetice se zřením k výtvarnému umění [Objective Method in Aesthetics with a Focus on Fine Arts]. In Univerzitní Studie. Prague: Československý Spisovatel, pp. 121-260. First published in 1915.

Čapek, Karel. 1987. Pragmatismus čili Filosofie praktického života [Pragmatism, Or Philosophy of Practical Life]. In Univerzitní Studie. Prague: Československý Spisovatel, pp. 261-338. First published in 1918. 
Čapek, Karel. 2018. Kapitoly z nové české filozofie [Chapters from New Czech Philosophy]. In Od Člověka k Člověku. Prague: Městská Knihovna v Praze, pp. 41-47. First published in 1918.

Čapek, Karel. 1985. Filosofie přítomnosti. Prof. dr. František Krejčí: Filozofie posledních let před válkou [Philosophy of the Present. Prof. dr. František Krejčí: Philosophy of the Last Years before the War]. In O Umění a Kultuře II. Prague: Československý Spisovatel, pp. 94-97. First published in 1919.

Čapek, Karel. 1995. Obecné pravdy [Common Truths]. In O Umění a Kultuře. Od Člověka k Člověku: Dodatky. Prague: Český Spisovatel, p. 91. First published in 1919.

Čapek, Karel. 1985. Filozofie Bergsonova. Henri Bergson: Vývoj tvořivý [The Philosophy of Bergson. Henri Bergson: Creative Evolution]. In O Umění a Kultuře II. Prague: Československý Spisovatel, pp. 159-87. First published in 1920.

Čapek, Karel. 2016. Pilátovo krédo [Pilate's Credo]. In Kniha Apokryfu. Prague: Vyšehrad, pp. 105-9. First published in 1920.

Čapek, Karel. 1982. Továrna na Absolutno [The Absolute at Large]. Prague: Československý Spisovatel. First published in 1922.

Čapek, Karel. 1985. Musím dále [I have to Go On]. In O Umění a Kultuře II. Prague: Československý Spisovatel, pp. 414-16. First published in 1922.

Čapek, Karel. 2005. Věc Makropulos [The Makropulos Case]. Prague: Artur. First published in 1922.

Čapek, Karel. 1995. Význam R.U.R. [The Meaning of R.U.R.]. In O Umění a Kultuře. Od Člověka k Člověku: Dodatky. Prague: Český Spisovatel, pp. 156-60. First published in 1923.

Čapek, Karel. 1966. Jak vzniklo slovo robot [How the Word Robot Come About]. In R.U.R.: Rossum's Universal Robots: Kolektivní Drama o Vstupní Komedii a Třech Dějstvích. 20. Vyd. Prague: Československý Spisovatel, p. 105. First published in 1924.

Čapek, Karel. 2000a. O pesimismu [About Pessimism]. In O Věcech Obecných, Čili, Zoon Politikon. Prague: Hynek, pp. 53-55. First published in 1924.

Čapek, Karel. 2000b. Proč nejsem komunistou [Why I'm Not a Communist]. In O Věcech Obecných, Čili, Zoon Politikon. Prague: Hynek, pp. 76-86. First published in 1924.

Čapek, Karel. 2000a. List Jaroslavu Durychovi o katolících [A Letter to Jaroslav Durych about Catholics]. In O Věcech Obecných, Čili, Zoon Politikon. Prague: Hynek, pp. 66-75. First published in 1926.

Čapek, Karel. 2000b. O amerikanismu. Dopis vydavateli New York Sunday Times [About Americanism. Letter to the Publisher New York Sunday Times]. In O Věcech Obecných, Čili, Zoon politikon. Prague: Hynek, pp. 56-61. First published in 1926.

Čapek, Karel. 2000c. O relativismu [About Relativism]. In O Věcech Obecných, Čili, Zoon Politikon. Prague: Hynek, pp. 45-48. First published in 1926.

Čapek, Karel. 1986. Henri Bergson. In O Umění a Kultuře III. Prague: Československý Spisovatel, pp. 179-81. First published in 1929.

Čapek, Karel. 2000. O tyranii strojů. Dopis Daily Heraldu [About the Tyranny of Machines. A Letter to the Daily Herald]. In O Věcech Obecných, Čili, Zoon Politikon. Praha: Hynek, pp. 62-65. First published in 1930.

Čapek, Karel. 2000. Sám o sobě a o věcech závažnějších [On myself and on Other More Serious Matters]. In O Věcech Obecných, Čili, Zoon Politikon. Prague: Hynek, pp. 87-124. First published in 1932.

Čapek, Karel. 1986. O slově robot [About the Word Robot]. In O Umění a Kultuře III. Prague: Československý Spisovatel, pp. 502-3. First published in 1933.

Čapek, Karel. 2018. Pereat Mundus. In Od Človeka k Človeku III. Prague: Městská knihovna v Praze. First published in 1934.

Čapek, Karel. 1986. Dobrý Chesterton [The Good Chesterton]. In O Umění i Kultuřre III. Prague: Městská knihovna v Praze, p. 697. First published in 1936.

Čapek, Karel. 2016. Kniha Apokryfů [Apocryphal Tales]. Prague: Vyšehrad. First published in 1945.

Čapek, Josef. 1912. Postavení futuristů v dnešním umění [The Position of Futurists in Today's Art]. Umělecký Měsičník 1: 174-78.

Čapek, Karel. 1920. R. U. R. (Rossum's Universal Robots). Prague: Otokar Štorch-Marien Aventinum.

Čapek, Karel. 1923. R. U. R. Rossum 's Universal Robots. Translated by Paul Selver. Garden City: Doubleday, Page \& Co.

Čapek, Karel. 1987. Univerzitní Studie [University Study]. Prague: Československý Spisovatel.

Čapek, Karel. 1990. R.U.R.: Rossum’s Universal Robots. In Toward the Radical Center: A Karel Čapek Reader. Edited by Peter Kussi. North Haven: Catbird Press.

Čapek, Karel, and Josef Čapek. 1982. Krakonošova Záhrada [The Garden of Krakonoš]. Prague: Československý Spisovatel. First published in 1918.

Čapek, Josef, and Karel Čapek. 1982. Adam Stvořitel [Adam the Creator]. Prague: Československý Spisovatel. First published in 1927.

Catalano, Alessandro. 2013. Hledání Nového Umění Před První Světovou Válkou [Searching for New Art before the First World War]. Souvislosti: Revue pro Literaturu a Kulturu, Available online: http:/ / www.souvislosti.cz/clanek.php?id=1568 (accessed on 16 December 2020).

Černý, František. 2000. Premiéry Bratři Čapků [Premieres of the Čapek Brothers]. Prague: Hynek.

Chesterton, Gilbert K. 1986. The Leisure State and the Liberty State. In Collected Works of GK Chesterton. San Francisco: Ignatius Press, vol. 33, pp. 134-38. First published in 1923.

Ćirković, Milan M. 2020. Anthropocentrism and the Roots of Resistance to Both Human Bioenhancement and Space Colonization. In Human Enhancements for Space Missions. Edited by Konrad Szocik. Cham: Springer, pp. 265-78.

Clarke, Frederick I. 2000. The Tales of the Last Days, 1805-3794. In Imagining Apocalypse. Edited by David Seed. London: Palgrave Macmillan, pp. 15-26.

Delio, Ilia. 2020. Suffering and Sacrifice in an Unfinished Universe: The Energy of Love. Religions 11: 335. [CrossRef] 
Di Genio, Giuseppe. 2021. The Death of Death. Il far west della cryopreservation nel diritto pubblico comparator. BioLaw Journal Rivista di BioDiritto 8: 255-65. [CrossRef]

Durych, Jaroslav, Jaroslav Med, and Zuzana Fialová. 2001. List Karlu Čapkovi o loajalitě [A Letter to Karel Čapek about Loyalty]. In Publicista. Edited by Jaroslav Durych. Praque: Academia, pp. 202-8. First published in 1926.

Ferrando, Francesca. 2015. Of posthuman born: Gender, utopia and the posthuman in films and TV. In The Palgrave Handbook of Posthumanism in Film and Television. Edited by Michael Hauskeller, Thomas D. Philbeck and Curtis D. Carbonell. London: Palgrave Macmillan, pp. 269-78.

Ferrando, Francesca. 2019. Philosophical Posthumanism. London and New York: Bloomsbury Publishing.

Fox, Stephen. 2018. Cyborgs, Robots and Society: Implications for the Future of Society from Human Enhancement with In-The-Body Technologies. Technologies 6: 50. [CrossRef]

Frunză, Sandu. 2019. Human Condition and the Sacred in the Digital Era. Journal for the Study of Religions and Ideologies 18: 156-69.

Geraci, Robert M. 2020. A hydra-logical approach: Acknowledging complexity in the study of religion, science, and technology. Zygon ${ }^{\circledR}$ 55: 948-70. [CrossRef]

Grech, Marija. 2016. Proto-Posthumanisms. Word and Text. A Journal of Literary Studies and Linguistics 6: 5-8.

Grübler, Gerd. 2014. Android Robots between Service and the Apocalypse of the Human Being. In Robotics in Germany and Japan. Philosophical and Technical Perspectives. Edited by Michael Funk and Bernhard Irrgangby. Berlin: Peter Lang, pp. 147-61.

Halík, Tomáš. 2008. Čapkúv obraz Boha-Moudrá a laskavá instance [Čapek's Image of God—A Wise and Kind Instance]. Katolický Týdeník 19: 4-5.

Halík, Tomáš. 2018. Čapek jako vychovávatel [Čapek as an Educator]. Katolický Týdeník 29: 4.

Harkins, William E. 1962. Karel Čapek. New York, Chichester and West Sussex: Columbia University Press.

Horáková, Jana. 2005. RUR-Comedy about Robots. In DISK, Selections from the Czech Journal of the Study of Dramatic Arts I. Edited by Július Gajdoš. Prague: Academy of Performing Arts in Prague, pp. 86-103.

Horáková, Jana, and Jozef Kelemen. 2008. The Robot Story: Why Robots Were Born and How They Grew Up. In The Mechanical Mind in History. Edited by Philip Husbands, Owen Holland and Michael Wheeler. Cambridge and London: A Bradford Book, The MIT Press, pp. 283-306.

Horáková, Jana, and Jozef Kelemen. 2009. Artificial Living Beings and Robots: One Root, Variety of Influences. Artificial Life and Robotics 13: 555-60. [CrossRef]

Howell, Yvonne. 1984. Karel Capek in 1984. In Cross Currents: A Yearbook of Central European Culture \#03. Edited by Ladislav Matejka and Benjamin A. Stolz. Ann Arbor: Michigan Slavic Publications, pp. 121-30.

Chesi, Giulia Maria, and Francesca Spiegel. 2020. Theoretical Introduction: The Subject of the Human. In Classical Literature and Posthumanism. Edited by Giulia Maria Chesi and Francesca Spiegel. London: Bloomsbury Academic, pp. 1-20.

Jones, Raya. 2017. Archaic Man Meets a Marvelous Automaton: Posthumanism, Social Robots, Archetypes. Journal of Analytical Psychology 62: 338-55. [CrossRef] [PubMed]

Jones, Donna V. 2018. Inheritance and Finitude: Toward a Literary Phenomenology of Time. ELH 85: 289-303. [CrossRef]

Karaba, Miroslav. 2021. Following the Footsteps of John Polkinghorne: In Search of Divine Action in the World. Religions 12: 263. [CrossRef]

Katsev, Igor. 2021. How to Say Robot in Different Languages. Different Languages. Available online: https://www.indifferentlanguages. com/words/robot (accessed on 9 February 2020).

Keating, Jennifer, and Illah Nourbakhsh. 2019. Rossum's Mimesis. In Cyborg Futures. Social and Cultural Studies of Robots and AI. Edited by Teresa Heffernan. Cham: Palgrave Macmillan, pp. 141-58. [CrossRef]

Kimura, Takeshi. 2017. Robotics and AI in the Sociology of Religion: A Human in Imago Roboticae. Social Compass 64: 6-22. [CrossRef]

Kinyon, Kamila. 1999. The Phenomenology of Robots: Confrontations with Death in Karel Čapek's "R. U.R." Science Fiction Studies 26: 379-400.

Klíma, Ivan. 2002. Karel Čapek: Life and Work. North Haven: Catbirdpress.

Klíma, Ivan. 2004. Introduction. In R.U.R.: Rossum 's Universal Robots. Translated by Claudia Novack-Jones. New York: Penguin, pp. $7-25$.

Knox, Jeremy. 2016. Posthumanism and the Massive Open Online Course: Contaminating the Subject of Global Education. New York: Routledge.

Komárek, Karel. 2014. Čep, Durych a Několik Přibuzných: Interpretační Studie [Čep, Durych and Some Relatives: Interpretation Study]. Olomouc: Vydavatelství Filozofické fakulty Univerzity Palackého v Olomouci.

Koreis, Voyen. 2008. Introduction and Translation Notes. In Karel Čapek Two Plays by Karel Čapek: R.U.R. (Rossum's Universal Robots) E The Robber. Brisbane: Booksplendour Publishing, pp. 3-10.

LaGrandeur, Kevin. 2015. Androids and the Posthuman in Television and Film. In The Palgrave Handbook of Posthumanism in Film and Television. Edited by Michael Hauskeller, Thomas D. Philbeck and Curtis D. Carbonell. London: Palgrave Macmillan, pp. 111-19.

Lamač, Miroslav. 1988. Osma a skupina výtvarných umělcu 1907-1917 [The Eighth and the Group of Visual Artists 1907-1917]. Prague: Odeon. Langer, František. 1971. Byli a Bylo [They Were and It Was]. Prague: Československý Spisovatel.

Liu, Lydia H. 2010. The Freudian Robot: Digital Media and the Future of the Unconscious. Chicago: University of Chicago Press.

Marinetti, Filippo T. 2006. The Foundation and Manifesto of Futurism. In F.T. Marinetti Critical Writings. Edited by Günter Berghaus. Translated by Doug Thompson. New York: Farrar, Straus and Giroux, pp. 11-17. First published in 1909. 
Marinetti, Filippo T. 2006. Extended Man and the Kingdom of the Machine. In F.T. Marinetti Critical Writings. Edited by Günter Berghaus. Translated by Doug Thompson. New York: Farrar, Straus, and Giroux, pp. 85-88. First published in 1910.

Med, Jaroslav. 2006. Španělská Občanská Válka: Neuralgický Bod Literárního Života [The Spanish Civil War: The Neuralgic Point of Literary Life]. Česká Literatura 54: 1-18.

Münster, Reinhold. 2020. The Anthropocene, Technology and Fictional Literature. Humanities 9: 56. [CrossRef]

Nakamura, Miri. 2007. Marking bodily differences: Mechanized bodies in Hirabayashi Hatsunosuke's 'Robot' and early Showa robot literature. Japan Forum 19: 169-90. [CrossRef]

Naughton, James D. 1984. Futurology and Robots: Karel Čapek's RUR. Culture, Theory and Critique 28: 72-86.

Nelis, Jan, Anne Morelli, and Danny Praet. 2015. Catholicism and Fascism in Europe 1918-1945. Hildesheim: Georg Olms Verlag.

Normandin, Sebastian, and Charles T. Wolfe. 2013. Vitalism and the scientific image: An introduction. In Vitalism and the Scientific Image in Post-Enlightenment Life Science, 1800-2010. Edited by Sebastian Normandin and Charles T. Wolfe. Dordrecht: Springer, pp. 1-15.

Odorčák, Juraj. 2021. Homo Artefactus and Promethean Shame: Reflections on Josef Čapek, Futurism, Transhumanism, Posthumanism, and the Obvious. World Literature Studies 13: 2.

Opelík, Jiří. 2016. Uklizený Stůl Aneb Moje Druhá Knížka o Karlu Čapkovi: A Opět s Jedním Přívažkem o Josefovi [Tidy Table or My Second Book about Karel čApek: And Again with One Addition about Josef]. Praque: Torst.

Ort, Thomas. 2013. Art and Life in Modernist Prague: Karel Čapek and His Generation, 1911-1938. New York: Palgrave Macmillan.

Parrinder, Patrick. 2015. Utopian Literature and Science. From the Scientific Revolution to Brave New World and Beyond. London: Palgrave Macmillan.

Philmus, Robert M. 2001. Matters of Translation: Karel Čapek and Paul Selver. Science Fiction Studies 28: 7-32.

Pilný, Ondřej. 2021. The Brothers Čapek at the Gate: RUR and The Insect Play. In Cultural Convergence: The Dublin Gate Theatre, 1928-1960. Edited by Ondřej Pilný, Ruud van den Beuken and Ian Walsh R. Cham: Palgrave Macmillan, pp. 141-73.

Pisarski, Mariusz. 2021. Human, Super-Human, Anti-Human: The Posthuman Deep Future in Evolutionary Science Fiction. World Literature Studies 13: 2.

Porter, Allen. 2017. Bioethics and Transhumanism. The Journal of Medicine and Philosophy: A Forum for Bioethics and Philosophy of Medicine 42: 237-60. [CrossRef] [PubMed]

Potkonjak, Veljko. 2020. Is Artificial Man Still Far Away: Anthropomimetic Robots Versus Robomimetic Humans. Robotics 9: 57. [CrossRef]

Průcha, Václav. 2004. Hospodářské a Sociální Dějiny Československa 1918-1992. 1. díl. Období 1918-1945 [Economic and Social History of Czechoslovakia 1918-1992. Part 1. Period 1918-1945]. Brno: Nakladatelství Doplněk.

Pugh, Jeffrey C. 2017. The Disappearing Human: Gnostic Dreams in a Transhumanist World. Religions 8: 81. [CrossRef]

Putna, Martin C. 2008. Katolická Prosba Karlu Čapkovi o Odpuštění [Catholic Request to Karel Čapek for Forgiveness]. Lidové Noviny. Available online: https://www.lidovky.cz/noviny/katolicka-prosba-karlu-capkovi-o-odpusteni.A081227_000005_ln_noviny_ sko (accessed on 17 December 2020).

Renč, Václav. 1939. Smrt Karla Čapka [The Death of Karel Čapek]. Národní Obnova 2: 6.

Richardson, Kathleen. 2015. An Anthropology of Robots and AI: Annihilation Anxiety and Machines. New York: Routledge.

Rosenfeld, Azriel. 1966. Religion and the Robot. Tradition: A Journal of Orthodox Jewish Thought 8: 15-26.

Sayer, Derek. 2018. Between Karel Čapek and a Hard Brexit. Reflections on Robotics and Humanity New Perspectives 26: 115-27. [CrossRef]

Schade, Leach D., and Emily Askew. 2019. What I've Seen with Your Eyes: Relational Theology and Ways of Seeing in Blade Runner. Religions 10: 625. [CrossRef]

Scheufler, Pavel. 2000. Karel Čapek Photographer. Prague: Obecní dům.

Schinzel, Britta. 2021. Where from and Where to: Transhumanistic and Posthumanistic Phantasms: Antichrist, Headbirth and the Feminist Cyborg. In Transhumanism: The Proper Guide to a Posthuman Condition or a Dangerous Idea? Edited by Wolfgang Hofkirchner and Hans-Jörg Kreowski. Cham: Springer, pp. 204-24.

Sigmund, Tomáš. 2017. Motives of Transhumanism. Proceedings 1: 242. [CrossRef]

Šiška, Jakub. 2010. Karel Čapek a Víra [Karel Čapek and Faith]. Český Rozhlas. Témata 6. Available online: https:/ /temata.rozhlas.cz/ karel-capek-a-vira-7998906 (accessed on 10 February 2021).

Sleigh, Charlotte. 2009. Plastic Body, Permanent Body: Czech Representations of Corporeality in the Early Twentieth Century. Studies in History and Philosophy of Science Part C. Studies in History and Philosophy of Biological and Biomedical Sciences 40: 241-55. [CrossRef]

Sparks, Julie A. 1997. Shaw for the Utopians, Čapek for the Anti-Utopians. Shaw 17: 165-83.

Sriratana, Verita. 2018. ... and Miraculously Post-Modern Became Ost-Modern: How On or About 1910 and 1924 Karel Čapek Helped to Add and Strike off the 'P'. Acta Universitatis Sapientiae, European and Regional Studies 14: 7-22. [CrossRef]

Strätz, Juliane. 2017. The Ordeal of Labor and the Birth of Robot Fiction. Amerikastudien/American Studies 62: 633-48.

Vášová, Věra. 1930. Karel Čapek s Hlediska Náboženského [Karel Čapek from the Religious Point of View]. Prague: YMCA v Československu, vydavatelské oddělení.

Veis, Jaroslav. 2020. Sto let Od Zrodu Českého Robota Aneb Karel Čapek a Isaac Asimov [One Hundred Years Since the Birth of the Czech Robot or Karel Čapek and Isaac Asimov]. Česká pozice. Available online: https:/ / ceskapozice.lidovky.cz/tema/sto-let-odzrodu-ceskeho-robota-aneb-karel-capek-a-isaac-asimov.A200211_164406_pozice-tema_lube (accessed on 15 February 2021). 